\title{
Australian Journal of

\section{Efficacy of organomineral fertilizers derived from biosolid or filter cake on early maize development}

\section{Mara Lúcia Martins Magela†*, Reginaldo de Camargo*, Regina Maria Quintão Lana, Melissa Cristina de Carvalho Miranda, Raquel Pinheiro da Mota}

Federal University of Uberlândia (UFU) - Campus Umuarama, Agrarian Science Institute (ICIAG). Address: Av. Amazônas, n/n, build 2E-150. Uberlândia, MG state, Brazil

\author{
*Corresponding author: maralumm@hotmail.com; rcamargo@ufu.br \\ tThis work is part of the master's thesis of the first author.
}

\begin{abstract}
In the current world scenario of agriculture it is necessary to find technologies to reach high productivity that are effective in providing soil conditioning improvement for the plants. Thus, this study analyzed the efficacy of organomineral fertilizers formulated with different organic matter sources on growth factors of maize. The experiment was done in a greenhouse at Campus Umuarama, Federal University of Uberlândia-MG, in a randomized block design, as a $2 \times 5+2$ factorial, containing two sources of organic matter, biosolid and filter cake, five doses of $\mathrm{P}_{2} \mathrm{O}_{5}$ recommendation for the crop and two additional treatments: mineral fertilization (100\% of $\mathrm{P}_{2} \mathrm{O}_{5}$ of the recommended dose) and a control (no fertilizer), with four replications. Plant height, stalk diameter, and chlorophyll a and b were determined at 35 days after sowing (DAS); plant height, stalk diameter, shoot and root fresh and dry matter were determined at 65 DAS. The organomineral sources with biosolid and filter cake yielded greater height and diameter at 35 DAS than those of mineral fertilization. Regardless of the fertilizer organic matter source, stalk diameter at 35 DAS presented linear increase with increasing doses of the fertilizer sources. The use of fertilizer based on biosolid resulted in greater shoot fresh matter than the filter cake source, regardless of dose applied. In general, greater results were obtained for root fresh and dry matter at the greater fertilizer doses in comparison with the mineral fertilization. Organomineral fertilizers can be a viable alternative for partial or total substitution of mineral fertilization, since similar or better results were found for maize growth characteristics.
\end{abstract}

Keywords: Fertilization, organic residues, plant nutrition, sustainability, pelletized.

Abbreviations: DAS_days after sowing.

\section{Introduction}

Corn cultivation in Brazil has become highly technical and attentive to the pursuit of profitability based on greater efficiency of the productive processes including the incorporation of sustainability concepts during all stages of crop management. In this sense, the concern with the use of fertilizers intensified the search for sources capable of providing nutrients in a more synchronized way to the requirement of the crop in adequate quantity and form.

Organomineral fertilizers are an alternative fertilizer technology compared to mineral fertilization exclusively. They incorporate environmental benefits and soil fertility construction, and they use environmental liabilities, intensify the availability of nutrients to the plants, and reduce nutrient losses by leaching, volatilization and fixation processes (Benites et al., 2010; Borsari, 2013; Tiritan et al., 2012). The organomineral fertilizer is the result of the combination of organic and mineral fertilizers that can be formulated from organic waste of various origins (Benites et al., 2010; Sousa et al., 2012a). Among these, the filter cake and the sewage sludge, formed in large quantities by the enterprises that generate them, stand out.
The possibility of combining organic sources and mineral sources into a single formulation constitutes a relevant technology in fertilizers, since it increases the efficiency of the nutrient sources, since the organic matter present in the fertilizer allows greater protection of the elements and favors the maintenance of the physical, chemical and microbiological characteristics of the soil.

The use of fertilizers has been widespread in Brazil with the potential to expand its use to other localities, since the installation of organomineral fertilizer plants can be carried out in any region, provided that there is abundant availability of organic waste and that the source of production of the waste is near the factory. In addition, it is necessary that these residues are able to undergo a composting process, as can be done with the filter cake from sugarcane mills and also with treated sewage sludge from sewage treatment plants of urban centers.

The filter cake is a type of residue rich in organic matter, macro and micronutrients such as nitrogen, phosphorus, potassium, iron, manganese, copper and zinc and is generated in abundance by the sugar and alcohol industry. According to Korndörfer (2003), each ton of ground cane 
generates around $40 \mathrm{~kg}$ of filter cake. Sewage sludge, produced at Sewage Treatment Plants (STPS) in urban centers, also has a large part of its composition in organic matter, with the concentrations of its nutrients varying according to the sanitation treatment it receives, being able to provide good amounts of essential nutrients to the plants. For later use in agriculture, the sewage sludge is renamed "Biosolids" (Bettiol; Camargo, 2006; Melo; Marques, 2000; Nunes Júnior, 2008).

The US Department of Agriculture (USDA, 1980) considers a typical biosolid to contain $40 \%$ organic matter, $4 \%$ nitrogen, $2 \%$ phosphorus and $0.4 \%$ potassium. The elements $\mathrm{Ca}$ and $\mathrm{Mg}$ are found in small amounts, except for those biosolids which are cleansed by liming, and thus contain present large amounts of $\mathrm{Ca}$ and $\mathrm{Mg}$.

When comparing the organomineral fertilizers to the mineral soluble sources, it is evident that the former has a relatively lower chemical potential, however its solubilization occurs gradually during the development of the crop, thus being able to obtain similar agronomic efficiency and even superior efficiency compared to those provided by a fertilization conventional (Tozatti, 2013).

According to Kominko et al. (2017), it is found that organomineral fertilizers derived from sewage sludge and modified by the addition of mineral fertilizers, when properly treated, are suitable for soil application and have a comparable yield response with conventional fertilizers.

The main advantage of organomineral fertilizer derived from biosolids is the slow release of nutrients, due to the significant increase of soil organic matter (Kominko et al., 2017).

According to Anetor and Omueti (2014), researching maize, for all soils tested in Nigeria, organomineral fertilizer with the organic fraction derived from composting of poultry residue, proved to be effective in releasing $P$ to growth parameters of corn such as plant height, stem diameter and number of leaves. In addition, the soil chemical characteristics improved with application of organomineral fertilizer based on poultry residues and coffee husks, and are an excellent alternative for olive trees cultivated in Neosol Quartzarênico (Carvalho et al., 2014).

According to Lana et al. (2009), it is possible to correlate growth measures of the corn plant, such as plant height, stem diameter and volume with grain production, since these characteristics are highly correlated. This correlation is an important tool that can be used as a parameter to evaluate plant responses to fertilizers, with the advantage that it is possible to obtain advance information about the performance of the crop.

With increasing global environmental awareness, it becomes necessary to develop alternative products for use in agriculture that enable the reuse and recycling of materials. Therefore, organomineral fertilizers stand out as an important strategy in this context, since industrial and urban waste when used for the production of fertilizers can reduce the costs of its elimination and the dependence on mineral fertilizers in addition to the damages caused by its accumulation in the environment.

Treated sewage sludge, or biosolids, may be an organic matrix suitable for the production of organomineral fertilizers for large crops, just as filter cake is already in other crops, such as sugar cane. In this way, organic biosolids fertilizers can supply the nutritional demands for the maize crop and is a viable and efficient alternative of total or partial replacement of mineral fertilizers.

Considering the possibility of the use of residues such as sewage sludge and filter cake for fertilizer composition, the objective of this study was to evaluate the efficiency of organic matter sources in the formulation composition and levels of fertilization with organomineral fertilizers on the initial development of Corn crop.

\section{Results and Discussion}

\section{Height and stem Diameter of Plants}

Plant height at 35 and 65 days after sowing (DAS) and stem diameter at 65 DAS were not influenced by source and dose factors (Tables 1 and 2).

However, at 35 days after sowing, plant height and stalk diameter for all doses of organomineral fertilizers with biosolids and filter cake obtained higher results than absence of fertilization (Tables 1 and 2).

In the comparison with mineral fertilization, at 35 DAS, the organomineral source constituted of filter cake at the lowest dose ( $60 \%$ of $\mathrm{P}_{2} \mathrm{O}_{5}$ of the recommendation) provided similar height to the mineral fertilization. In the other dosages the growth was superior to mineral fertilization (Table 1).

For the stem diameter, the doses of the organomineral fertilizer with the two organic sources provided higher values than the one found by the mineral source from the $80 \%$ dose of the recommended one for the culture (Table 2 ). Overall, the results showed that at 35 DAS, organomineral sources led to higher initial corn growth, even at reduced dosages of $20 \%$ and $40 \%$ in relation to the recommended dose (120 kg of $\mathrm{P}_{2} \mathrm{O}_{5}$ ) for the crop. In addition, the biosolids formulated fertilizer has been able to mimic the results provided by the filter cake formulation, showing that the treated sewage sludge can be used for fertilization as much as the filter cake which is already commercially used with organomineral systems.

In relation to the additional treatments, the behavior of the sources of organic matter in the evaluation at 35 days after sowing indicates that the release of nutrients in the soil solution probably occurred more intensely in this first phase, since no differences in maize height were observed at 65 DAS when comparing the sources and their respective doses with the exclusively mineral source and the control (Table 1). The same trend for diameter was observed, except for the fertilizer with biosolids at the rate of $140 \%$ of the recommendation (168 $\mathrm{kg} \mathrm{ha}^{-1}$ of $\mathrm{P}_{2} \mathrm{O}_{5}$ ), that provided a larger diameter in relation to the absence of fertilizer (Table 2).

It is suggested that this result of plant height and stem diameter in the first evaluation phase was due to the availability of nutrients by the mineral part of the organomineral fertilizer occurring more intensely in the first 30 days, causing these characteristics to be highlighted in the treatments with organomineral sources. Afterwards, the release of nutrients became slower and more gradual, demonstrating no influence on the plant in these requirements for the next period of evaluation.

In a study conducted by Santana (2012) with the objective of evaluating the behavior of maize in no-tillage system in 
Table 1. Height of plants $(\mathrm{cm})$ at 35 and 65 days after sowing of maize submitted to different doses of organomineral fertilizer composed of biosolids and filter cake in relation to mineral fertilization and absence of fertilization.

\begin{tabular}{|c|c|c|c|c|}
\hline \multirow{3}{*}{$\begin{array}{l}\text { Percentage of } \\
\text { Phosphorous (\%) }\end{array}$} & \multicolumn{4}{|c|}{ Organomineral Fertilizer } \\
\hline & \multicolumn{2}{|c|}{35 days } & \multicolumn{2}{|c|}{65 days } \\
\hline & Biosolids & Filter Cake & Biosolids & Filter Cake \\
\hline 60 & ${ }^{1} 57.13^{\circ *}$ & $53.97^{*}$ & ${ }^{1} 118.66$ & 115.94 \\
\hline 80 & $58.76^{\circ *}$ & $57.89^{\circ *}$ & 117.11 & 125.96 \\
\hline 100 & $59.31^{\circ *}$ & $59.45^{\circ *}$ & 120.16 & 122.35 \\
\hline 120 & $59.82^{\circ *}$ & $59.22^{\circ *}$ & 120.83 & 117.03 \\
\hline 140 & $61.16^{\circ} *$ & $59.30^{\circ} *$ & 123.47 & 122.13 \\
\hline Average & 59.23 & 57.97 & 120.05 & 120.68 \\
\hline Mineral fertilization & \multicolumn{2}{|c|}{$47.86^{\circ}$} & \multicolumn{2}{|c|}{$120.20^{\circ}$} \\
\hline Absence of fertilization & \multicolumn{2}{|c|}{$43.41 *$} & \multicolumn{2}{|c|}{$117.33 *$} \\
\hline & \multicolumn{2}{|c|}{$C V \%=6.27$} & \multicolumn{2}{|c|}{$\mathrm{CV} \%=7.96$} \\
\hline & \multicolumn{2}{|c|}{$\mathrm{DMS}_{\text {Dunnett }}=7.2656$} & \multicolumn{2}{|c|}{$\mathrm{DMS}_{\text {Dunnett }}=19.6209$} \\
\hline & \multicolumn{2}{|c|}{$\mathrm{DMS}_{\text {source }}=2.27962$} & \multicolumn{2}{|c|}{$\mathrm{DMS}_{\text {source }}=6.15612$} \\
\hline & \multirow{2}{*}{\multicolumn{2}{|c|}{$\begin{array}{c}{ }^{2} \mathrm{~W}=0.984 ; \mathrm{F} \text { lev }=1.947 \\
\text { F adit }=1.609\end{array}$}} & \multirow{2}{*}{\multicolumn{2}{|c|}{$\begin{array}{c}{ }^{2} \mathrm{~W}=0.986 ; \mathrm{F} \text { lev }=1.830 \\
\text { F adit }=2.091\end{array}$}} \\
\hline & & & & \\
\hline
\end{tabular}

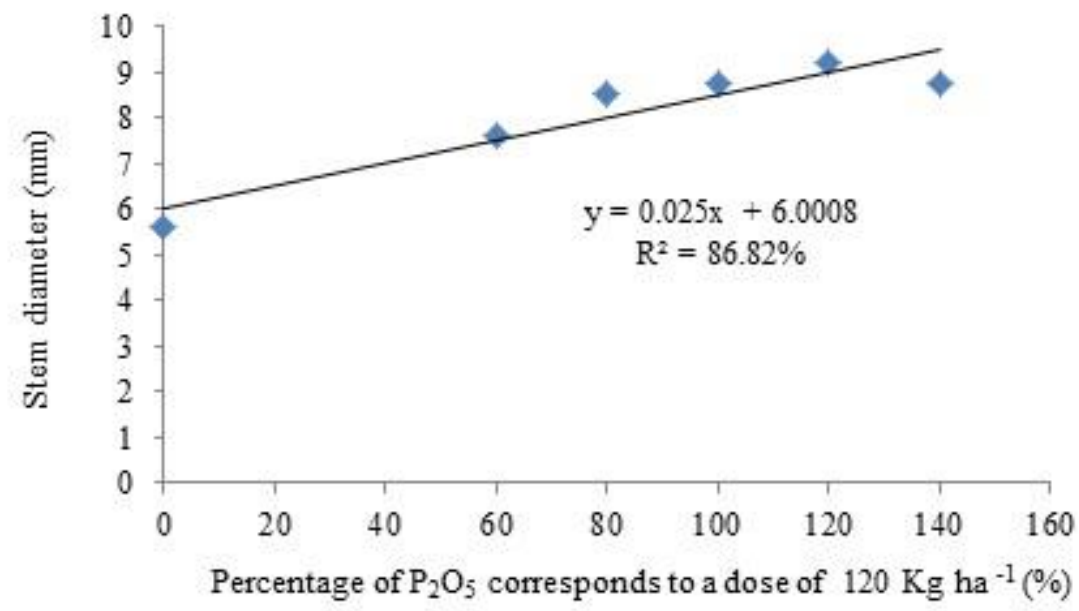

Fige 1. Stem diameter $(\mathrm{mm})$ of corn at 35 days after sowing as a function of the application of doses of organomineral fertilizer based on biosolid. Percentage of $\mathrm{P}_{2} \mathrm{O}_{5}$ corresponding to dose of $120 \mathrm{Kg} \mathrm{ha}^{-1}(\%)$.

Table 2. Stem diameter $(\mathrm{mm})$ at 35 and 65 days after sowing of maize submitted to different doses of organomineral fertilizer composed of biosolids and filter cake in relation to mineral fertilization and absence of fertilization.

\begin{tabular}{|c|c|c|c|c|}
\hline \multirow{3}{*}{$\begin{array}{l}\text { Percentage of } \\
\text { Phosphorous (\%) }\end{array}$} & \multicolumn{4}{|c|}{ Organomineral Fertilizer } \\
\hline & \multicolumn{2}{|c|}{35 days } & \multicolumn{2}{|c|}{65 days } \\
\hline & Biosolids & Filter Cake & Biosolids & Filter Cake \\
\hline 60 & $17.61 *$ & $7.56 *$ & 9.89 & 9.60 \\
\hline 80 & $8.54^{\circ *}$ & $9.00^{\circ} *$ & 9.81 & 10.05 \\
\hline 100 & $8.78^{\circ *}$ & $8.63^{\circ *}$ & 10.31 & 10.20 \\
\hline 120 & $9.24^{\circ *}$ & $8.34^{\circ *}$ & 10.03 & 9.97 \\
\hline 140 & $8.74^{\circ *}$ & $8.56^{\circ *}$ & $10.48 *$ & 10.29 \\
\hline Average & 8.58 & 8.42 & 10.10 & 10.02 \\
\hline Mineral fertilization & \multicolumn{2}{|c|}{$6.84^{\circ}$} & \multicolumn{2}{|c|}{$10.25^{\circ}$} \\
\hline Absence of fertilization & \multicolumn{2}{|c|}{$5.60 *$} & \multicolumn{2}{|c|}{$9.30 *$} \\
\hline & \multicolumn{2}{|c|}{$\mathrm{CV} \%=8.40$} & \multicolumn{2}{|c|}{$\mathrm{CV} \%=5.40$} \\
\hline & \multicolumn{2}{|c|}{$\mathrm{DMS}_{\text {Dunnett }}=1.39910$} & \multicolumn{2}{|c|}{$\mathrm{DMS}_{\text {Dunnett }}=1.1104$} \\
\hline & \multicolumn{2}{|c|}{$\mathrm{DMS}_{\text {source }}=0.43897$} & \multicolumn{2}{|c|}{$\mathrm{DMS}_{\text {source }}=0.3484$} \\
\hline & \multicolumn{2}{|c|}{${ }^{2} \mathrm{~W}=0.988 ; \mathrm{F}$ lev $=1.313 ; \mathrm{F}$ adit $=0.025$} & \multicolumn{2}{|c|}{${ }^{2} \mathrm{~W}=0.995 ; \mathrm{F}$ lev $=1.041 ; \mathrm{F}$ adit $=0.526$} \\
\hline
\end{tabular}




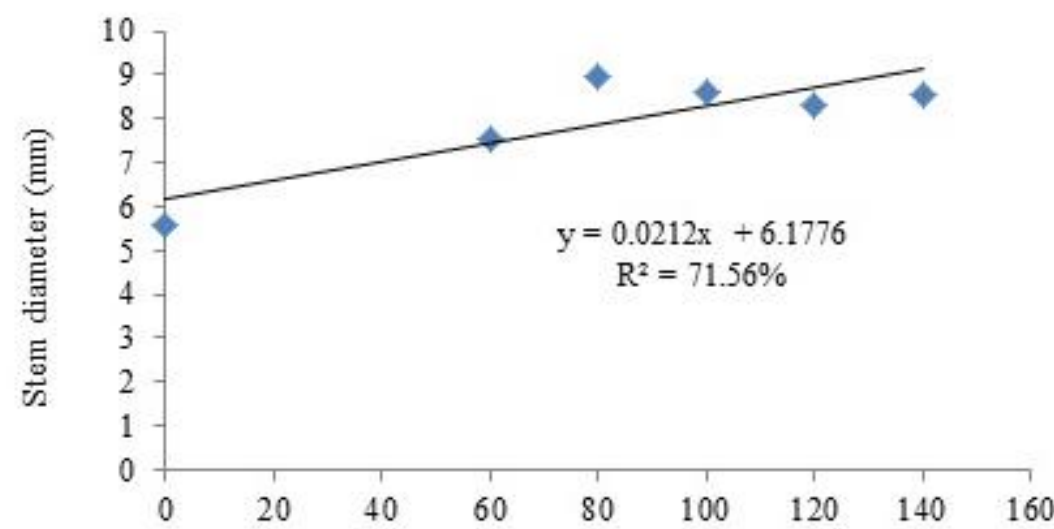

\section{Percentage of $\mathrm{P}_{2} \mathrm{O}_{5}$ corresponds to a dose of $120 \mathrm{Kg} \mathrm{ha}^{-1}(\%)$}

Fig 2. Stem diameter $(\mathrm{mm})$ of corn at 35 days after sowing as a function of the application of doses of organomineral fertilizer based on filter cake. Percentage of $\mathrm{P}_{2} \mathrm{O}_{5}$ corresponding to dose of $120 \mathrm{Kg} \mathrm{ha}^{-1}$ (\%).

Table 3. Green and dry mass of shoots $(\mathrm{g})$ at 65 days after sowing of maize submitted to different doses of organomineral fertilizer composed of biosolids and filter cake in relation to mineral fertilization and absence of fertilization

\begin{tabular}{|c|c|c|c|c|}
\hline \multicolumn{5}{|c|}{ Organomineral Fertilizer } \\
\hline \multirow[b]{2}{*}{$\begin{array}{l}\text { Percentage of } \\
\text { Phosphorous (\%) }\end{array}$} & \multicolumn{2}{|c|}{ Gren mass } & \multicolumn{2}{|c|}{ Dry mass } \\
\hline & Biosolids & Filter Cake & Biosolids & Filter Cake \\
\hline 60 & ${ }^{1} 125.73$ & 110.92 & 12.92 & 12.73 \\
\hline 80 & $154.41 *$ & 132.72 & 14.43 & 14.36 \\
\hline 100 & 138.24 & 130.06 & 13.35 & 14.25 \\
\hline 120 & 144.76 & 130.83 & 14.67 & 13.05 \\
\hline 140 & 141.36 & 140.12 & 14.79 & 15.50 \\
\hline Average & $140.90 \mathrm{a}$ & $128.93 b$ & $14.03 \mathrm{a}$ & $13.98 \mathrm{a}$ \\
\hline Mineral fertilization & $126.99^{\circ}$ & & $12.24^{\circ}$ & \\
\hline \multirow{2}{*}{ Absence of fertilization } & $110.92 *$ & & $11.52 *$ & \\
\hline & $\begin{array}{c}C V \%=13.39 \\
D M S \text { Dunnet }=36.3339 \\
D M S_{\text {surce }}=11.3998 \\
{ }^{2} \mathbf{W}=\mathbf{0 . 9 5 9 ;} \text { F lev= } \mathbf{1 . 0 8 8 ;} \text { F adit= } \mathbf{2 . 4 8 1}\end{array}$ & & $\begin{array}{l}C V \%=18.30 \\
\text { DMS Dunnett }=5.1265 \\
D M S_{\text {source }}=1.6084 \\
{ }^{2} \mathbf{W}=0.977 ; \text { F lev }=1.7\end{array}$ & \\
\hline
\end{tabular}

Levene and Tukey tests for additivity, respectively; values in bold indicate residues with normal distribution, homogeneous variances and additivity, all at 0.01 of significance.

Table 4. Green and dry mass of roots (g) at 65 days after sowing of maize submitted to different doses of organomineral fertilizer composed of biosolids and filter cake in relation to mineral fertilization and absence of fertilization.

\begin{tabular}{|c|c|c|c|c|}
\hline \multicolumn{5}{|c|}{ Organomineral Fertilizer } \\
\hline & \multicolumn{2}{|c|}{ Gren mass } & \multicolumn{2}{|c|}{ Dry mass } \\
\hline \multirow{2}{*}{$\begin{array}{l}\text { Percentage of } \\
\text { Phosphorous (\%) }\end{array}$} & \multicolumn{2}{|c|}{35 days } & \multicolumn{2}{|c|}{65 days } \\
\hline & Biosolids & Filter Cake & Biosolids & Filter Cake \\
\hline 60 & 136.92 & 35.13 & 4.97 & 5.52 \\
\hline 80 & 41.56 & 38.31 & 6.83 & 5.46 \\
\hline 100 & $47.03^{\circ *}$ & 38.04 & 7.24 & 5.63 \\
\hline 120 & 41.20 & $44.99^{\circ}$ & 5.78 & 7.43 \\
\hline 140 & $52.37^{\circ *}$ & $46.68^{\circ *}$ & $16.78^{\circ} *$ & 8.31 \\
\hline Average & 43.81 & 40.63 & 8.32 & 6.47 \\
\hline Mineral fertilization & \multicolumn{2}{|c|}{$27.96^{\circ}$} & \multicolumn{2}{|c|}{$3.19^{\circ}$} \\
\hline Absence of fertilization & \multicolumn{2}{|c|}{$31.24 *$} & \multicolumn{2}{|c|}{$4.68 *$} \\
\hline & $\mathbf{W}=\mathbf{0 . 9 6 5}$ & $\begin{array}{l}1 \\
2532 \\
720 \\
F \text { adit }=0.43\end{array}$ & \multicolumn{2}{|c|}{$\begin{array}{c}\mathrm{CV} \%=66.59 \\
\mathrm{DMS}_{\text {Dunnett }}=9.31506\end{array}$} \\
\hline
\end{tabular}

1 ㅇ and *: different by the Dunnett test at 0.05; Averages followed by distinct letters on the line differ from each other by the Tukey test a $0.05 .{ }^{2} \mathrm{~W}, \mathrm{~F}$ lev, F adit: statistics of Shapiro-Wilk, Levene and Tukey tests for additivity, respectively; values in bold indicate residues with normal distribution, homogeneous variances and additivity, all at 0.01 of significance. 
Table 5. Chlorophyll $a, b$ e Total at 35 days after sowing of maize submitted to different doses of organomineral fertilizer composed of biosolids and filter cake in relation to mineral fertilization and absence of fertilization.

\begin{tabular}{|c|c|c|c|c|c|c|c|}
\hline \multirow{3}{*}{$\begin{array}{l}\text { Percentage of } \\
\text { Phosphorous (\%) }\end{array}$} & \multicolumn{7}{|c|}{ Organomineral Fertilizer } \\
\hline & \multicolumn{2}{|c|}{ Cholorophyll $a$} & & \multicolumn{2}{|c|}{ Cholorophyll $b$} & \multicolumn{2}{|c|}{ Cholorophyll Total } \\
\hline & Biosolids & Filter Cake & & Biosolids & Filter Caker & Biosolids & Filter Caker \\
\hline 60 & ${ }^{1} 27.56$ & 25.13 & & ${ }^{1} 5.40$ & 4.66 & 132.96 & 29.79 \\
\hline 80 & 27.87 & 26.93 & & 5.30 & 5.25 & 33.17 & 32.18 \\
\hline 100 & 26.06 & 28.29 & & 5.47 & 5.64 & 31.53 & 33.93 \\
\hline 120 & 28.81 & 26.91 & & 6.11 & 5.29 & 34.92 & 32.20 \\
\hline 140 & 24.54 & 25.19 & & 5.01 & 5.03 & 29.54 & 30.23 \\
\hline Average & 26.97 & 26.49 & & 5.46 & 5.18 & 32.42 & 31.67 \\
\hline Mineral fertilization & \multicolumn{2}{|c|}{$24.20^{\circ}$} & & \multicolumn{2}{|c|}{$4.52^{\circ}$} & \multicolumn{2}{|c|}{$28.72^{\circ}$} \\
\hline \multirow[t]{2}{*}{ Absence of fertilization } & \multicolumn{2}{|c|}{$25.56 *$} & & \multicolumn{2}{|c|}{$4.73^{*}$} & \multicolumn{2}{|c|}{$30.29 *$} \\
\hline & \multicolumn{2}{|c|}{$\begin{array}{l}\mathrm{CV} \%=11.64 \mathrm{DMS}_{\text {Dunnett }}=6.3083 \\
\mathrm{DMS} \text { Source }=1.9792 \\
\mathbf{W}=\mathbf{0 . 9 7 9} ; \mathrm{F} \text { lev=2.298; } \\
\text { F adit= } \mathbf{0 . 8 2 1}\end{array}$} & \multicolumn{3}{|c|}{$\begin{array}{l}\mathrm{CV} \%=16.21 \\
\mathrm{DMS} \text { Dunnett }=1.7300 \\
\mathrm{DMS} \text { Source }=0.5428 \\
{ }^{2} \mathbf{W}=\mathbf{0 . 9 8 8 ;} \mathbf{F} \text { lev } \mathbf{2 . 3 6 4 ;} \\
\mathbf{F} \text { adit= } \mathbf{0 . 0 5 0}\end{array}$} & \multicolumn{2}{|c|}{$\begin{array}{l}\text { CV\% }=12.27 \\
D M S_{\text {Dunnett }}=7.9609 \\
D M S_{\text {source }}=2.4977 \\
{ }^{2} \mathbf{W}=\mathbf{0 . 9 7 8} ; \mathbf{F} \text { lev }=\mathbf{2 . 3 0 0} ; \\
\text { F adit= } \mathbf{0 . 5 0 2}\end{array}$} \\
\hline
\end{tabular}
and Tukey tests for additivity, respectively; values in bold indicate residues with normal distribution, homogeneous variances and additivity, all at 0.01 of significance.

Table 6. Doses and types of fertilizer evaluated for maize crop fertilization. Uberlândia, 2015.

\begin{tabular}{lcc}
\hline \multicolumn{1}{c}{ Fertilizers } & $\begin{array}{c}\text { * Percentage of } \\
\text { Phosphorous (\%) }\end{array}$ & $\begin{array}{c}\text { Doses of } \\
\mathrm{P}_{2} \mathrm{O}_{5}\left(\mathrm{~kg} \mathrm{ha}^{-1}\right)\end{array}$ \\
\hline Organomineral biosolids & 60 & 72 \\
Organomineral filter cake & 60 & 72 \\
Organomineral biosolids & 80 & 96 \\
Organomineral filter cake & 80 & 96 \\
Organomineral biosolids & 100 & 120 \\
Organomineral filter cake & 100 & 120 \\
Organomineral biosolids & 120 & 144 \\
Organomineral filter cake & 120 & 144 \\
Organomineral biosolids & 140 & 168 \\
Organomineral filter cake & 140 & 168 \\
Positive Control (mineral fertilization) & 100 & 120 \\
Negative Control (absence of fertilization) & - & - \\
\hline tage of phosphorus in relation to 100\% of the dose (120 $\mathrm{kg} \mathrm{ha}^{-1}$ ) recommended according to "Recommendation for use of correctives and fertilizers in Minas
\end{tabular}

Table 7. Chemical characterization of the Red Latosol sample. Uberlândia, 2015.

\begin{tabular}{|c|c|c|c|c|c|c|c|c|c|c|c|}
\hline $\mathbf{p H}_{\text {water }}(1: 2,5)$ & $\mathbf{P}_{\text {meh-1 }}$ & K & $\mathrm{Ca}^{2+}$ & $\mathrm{Mg}^{2+}$ & $\mathrm{Al}^{3+}$ & $\mathrm{H}+\mathrm{Al}$ & SB & & $\mathrm{t}$ & \multicolumn{2}{|l|}{$\mathbf{T}$} \\
\hline \multicolumn{2}{|c|}{$-----\mathrm{mg} \mathrm{dm}^{-3}-\mathrm{-}^{----}$} & ------ & 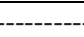 & 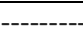 & $---\mathrm{cn}$ & $\mathrm{dm}^{-3}-$ & ------- & - & 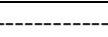 & \multirow{2}{*}{\multicolumn{2}{|c|}{6.21}} \\
\hline 6.2 & 2.3 & 0.31 & 2.3 & 0.8 & 0 & 2.8 & 3.41 & & 3.41 & & \\
\hline V & m & & O.M. & O.C & & & B & $\mathrm{Cu}$ & $\mathrm{Fe}$ & $M n$ & $\mathrm{Zn}$ \\
\hline \multicolumn{2}{|c|}{ 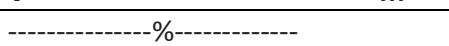 } & \multicolumn{3}{|c|}{------dag kg ${ }^{-1}------$} & & & \multicolumn{5}{|c|}{ - } \\
\hline 55 & 0 & & 2.7 & 1.6 & & & 0.07 & 8.6 & 10 & 7 & 1.7 \\
\hline
\end{tabular}

$\mathrm{P}, \mathrm{K}=\left(\mathrm{HCL} 0.05 \mathrm{~mol} \mathrm{~L}^{-1}+\mathrm{H}_{2} \mathrm{SO}_{4} 0.0125 \mathrm{~mol} \mathrm{~L}^{-1}\right) \mathrm{P}$ available (extractor Mehlich-1); $\mathrm{Ca}, \mathrm{Mg}$, Al (KCl 1 mol L-1); H+Al= (Buffer Solution - SMP a pH 7.5); SB= Sum of Bases; $\mathrm{t}=\mathrm{cation}$ exchange rate Effective; $\mathrm{T}=$ cation exchange rate at $\mathrm{pH} 7 \cdot \mathrm{V}=\mathrm{Base}$ Saturation; $\mathrm{m}=$ Saturation by Aluminum (EMBRAPA, 1997), Organic matter $-\mathrm{O} . \mathrm{M}=\mathrm{Colorimetric} \mathrm{Method} . \mathrm{B}=\left(\mathrm{BaCl} \cdot 2 \mathrm{H} \mathrm{H}_{2} 0.0125 \% \mathrm{hot}\right) ; \mathrm{Cu}, \mathrm{Fe}, \mathrm{Mn}, \mathrm{Zn}=$ (DTPA $0.005 \mathrm{~mol} \mathrm{~L}^{-1}+\mathrm{TEA} 0.1 \mathrm{~mol} \mathrm{~L}^{-1}+\mathrm{CaCl}_{2} 0.01 \mathrm{~mol} \mathrm{~L}^{-1}$ at pH 7.3). Organic carbon O.C.

Table 8. Chemical attributes of biosolids. Uberlândia, 2014.

\begin{tabular}{|c|c|c|c|c|c|c|c|c|c|c|c|}
\hline & $\mathrm{pH}_{\text {water }}(1: 2,5)$ & TOC & \multicolumn{3}{|c|}{$\mathrm{P}_{2} \mathrm{O}_{5}$ Total } & $\mathrm{K}_{2} \mathrm{O}$ & & \multicolumn{2}{|c|}{$\mathrm{C} / \mathrm{N}$ ratio } & $\mathrm{O} . \mathrm{M}$ & \\
\hline & & ------ & ------- & $\% \quad--$ & ------- & ----- & & & & - $\mathrm{g} \mathrm{Kg}^{-1}$ & \\
\hline \multirow[t]{4}{*}{ Biosolid } & 12.65 & 19.80 & & 2.23 & & 0.24 & & $28 / 1$ & & 368.60 & \\
\hline & C & $\mathbf{N}$ & $\mathrm{Na}$ & $\mathrm{Ca}$ & Mg & $\mathbf{P}$ & K & $S$ & Mn & $\mathrm{Fe}$ & Al \\
\hline & & & & $\mathrm{g} \mathrm{Kg}^{-1}$ & & & & -- & ---------. & $m g d m^{-3}$ & ----- \\
\hline & 213.80 & 20.88 & 0.61 & 302.0 & 4.2 & 1.6 & 0.6 & 12.4 & 138.75 & 12753.25 & 20104.53 \\
\hline & Cd & & $\mathrm{Pb}$ & & $\mathrm{Ni}$ & & $\mathrm{Cr}$ & & $\mathrm{Zn}$ & & $\mathrm{Cu}$ \\
\hline & 0.45 & & ND & & 19.86 & & 85.3 & & 1180 & & 157.91 \\
\hline
\end{tabular}

Characterized according to the Embrapa methodology (2013). TOC: Total organic carbon: amount of organic carbon in the sample. O.M: Organic Matter. C: Carbon: Important to assess the degree of waste, sice, as a result of the increase in of the composting time, there is a decrease in the of OM of the compoud. ND: Not detected 
Table 9. Chemical attributes of filter cake. Uberlândia, 2014.

\begin{tabular}{lllllll}
\hline & $\mathrm{pH}_{\text {water }}(1: 2,5)$ & $\mathrm{TOC}$ & $\mathrm{N}$ Total & $\mathrm{P}_{2} \mathrm{O}_{5}$ Total & $\mathrm{K}_{2} \mathrm{O}$ & $\mathrm{C} / \mathrm{N}$ ratio \\
\hline & & -23.49 & 0.61 & 0.95 & 0.30 & $13.72 / 1$ \\
\hline \multicolumn{2}{l}{ Filter Cake } & 6.81 & 23 Characterized according to the Embrapa methodology (2013). TOC: Total organic carbon.
\end{tabular}

response to fertilization with organomineral fertilizer, it was not observed any significant effect as a function of the application of formulated with this source on plant height, as well as in the diameter and insertion of the spike after 90 days of planting. Martins et al. (2016) also did not find any alterations in these characteristics due to the different organic sources in the composition of organomineral fertilizers and the use of different doses, but similarly to the present work, the comparison with the control without fertilization proved to be superior. Mendes et al. (2011), evaluating the efficiency of biosolids on vegetative parameters of maize crop, verified that the mean diameter of the stalks increased from the first sampling ( 45 days after emergence - DAE) in the treatments that received biosolids. However, at 75 DAE the superiority in diameter was verified for plants that received exclusively mineral fertilization.

At 35 DAS, regardless of sources, the dosages used influenced the stem diameter of maize (Table 2). The increase of the doses of the organomineral fertilizers provided a linear increase in the stalk diameter as the doses for the two sources of organic matter were increased. For every $1 \mathrm{~kg}$ of fertilizer with biosolids, there was an increase of $0.025 \mathrm{~mm}$ in the corn stalk (Figure 1), while in the application of the fertilizer with filter cake, this increase was $0.021 \mathrm{~mm}$ (Figure 2).

In another study (Anetor and Omueti, 2014), which aimed at the study of the application of source of organic matter with mineral sources in corn, it was observed an increase in plant height as a function of fertilizer application rates, and was reflected in higher yields. These results confirm the importance and efficiency of the joint application of organic matter with the mineral sources.

Kominko et al. (2017), studying organomineral fertilizers with sewage sludge, found that the yield of the crops was as good as those obtained by conventional fertilizers, attributing their results to the gradual release of the nutrients which is one of the main advantages of using the organomineral material. These authors also point out that the use of sewage sludge along with the mineral sources allows the produ ction of fertilizers with an optimal N, P and $\mathrm{K}$ ratio. Deeks et al. $(2013)$ compared the yield of wheat, rape, oleaginous, barley, beans and maize treated with conventional mineral fertilizers and organomineral fertilizers for three years and concluded that there were no differences in the yields of these crops, showing that this technology in fertilizer is so efficient as usually applied.

\section{Green and Dry Mass of Aerial Part}

Regarding the evaluation of green mass of the aerial part (Table 3), it was observed that, independent of the applied dose, the organomineral fertilizer based on biosolid provided a larger green mass than the source with filter cake, and it was verified that this increase was approximately $8 \%$.
Comparing the organomineral fertilizers in relation to mineral fertilization and the absence of fertilization, it was noticed that the dose of $80 \%$ of the recommendation increased the green mass in relation to the control while the other doses obtained similar values, and in comparison with mineral fertilization the green mass values were all similar.

This behavior in the green mass of the aerial part is very positive, since it demonstrates the potential of the use of the sources of organic raw materials (biosolid and filter cake) in the composition of organomineral fertilizers, being able to provide results similar to those found with exclusively mineral sources. However, the dry mass of aerial part of plants (Table 3) was not influenced by sources and doses of organomineral fertilizers, and no significant differences were observed in relation to chemical fertilization and absence of fertilization.

These results are distinct from those found by Teixeira (2013) in work conducted in sugarcane to evaluate the availability of phosphorus through mineral and organomineral fertilizers. This author verified that the dry matter accumulation obtained a linear increase in function of the doses regardless of the source used (organomineral and mineral fertilizer).

Teixeira (2013) also observed that there were increases in the treatments compared to the absence of fertilization, but no differences were observed between the sources, showing that the organomineral fertilizer obtained a similar efficiency to the mineral for the first cut of the sugar cane.

Tiritan et al. (2010) observed that the use of organomineral fertilizer in maize provided an equivalent dry mass efficiency 45 days after emergence, demonstrating the possibility of efficient use of this technology in fertilizers due to obtaining averages equal to or greater than those obtained by mineral fertilization.

The lack of observation of differences between fertilizers in the present work can be attributed to the fact that the nutrients present in the organic fraction of the organominerals are available at a lower speed in relation to the release of the nutrients provided by mineral sources.

Thus, in works with other crops developed over a longer period of time, such as the one conducted by Silva et al. (2012), it was observed that the use of organomineral fertilizer provided good dry mass performance in Brachiaria decumbens.

\section{Green and Dry Mass of Roots}

Regardless of organomineral fertilizer sources, increasing doses gave rise to differences in the accumulation of green and dry root mass (Table 4), however, no models were found that significantly represented the behavior of these variables in relation to fertilizer doses.

In general, higher results were obtained for the green and dry root mass for the higher doses of the two sources when compared to the additional ones (Table 4). 
The organomineral fertilizer with biosolids in the $100 \%$ and $140 \%$ doses and the organomineral with filter cake in the dose of $140 \%$, reached higher values of green mass in relation to the absence of fertilization. In the comparison with mineral fertilization, the increases remained with the $100 \%$ and $140 \%$ doses for the biosolid and with the doses of $120 \%$ and $140 \%$ for the filter cake.

These results demonstrate the efficiency of biosolids in promoting plant growth even at doses below the recommended level, because for the different growing doses this residue could be similar or superior in the increment of green root mass of maize plants. This may be a reflection of the initial growth in height and diameter of the plants.

It should be noted that at a dose of $140 \%$ of organomineral fertilizer with biosolid produced about $11 \%$ more green root mass compared to that produced with filter cake, while in relation to mineral fertilization, the increase was approximately $47 \%$ (Table 4). For root dry mass (Table 4), the $140 \%$ fertilizer dose with biosolids resulted in the greatest differences in relation to mineral fertilization and absence of fertilization. This result confirms the efficiency of biosolids in the composition of organomineral fertilizers, since the highest dose with this organic residue resulted in about $81 \%$ more of root dry mass than the plants that received mineral fertilization.

With higher doses of organomineral fertilizer there is greater availability of nutrients for the maize plant, mainly phosphorus. The organic matter present in organomineral fertilizers can increase the availability of phosphorus through the greater availability of negative charges. Among other factors, root growth is influenced by the availability of phosphorus in the soil, especially in the development of lateral and fibrous roots (Frazão, 2013). Thus, probably the higher doses of organomineral fertilizers allowed a greater amount of phosphorus in the soil solution, favoring the development of the corn root system.

\section{Chlorophyll $a, b$ and Total}

Another important characteristic in the evaluation of growth and development of the culture is the chlorophyll content (Table 5), which exerts influence in the realization of the photochemical stage, absorption of light and transfer of radiant energy to reaction centers (Streit et al., 2005).

No differences were observed in chlorophyll $a, b$ and total chlorophyll at 35 DAS, depending on sources and doses. Thus, these variables remained constant in relation to the treatments without demonstrating significant changes (Table 5). However, Oliveira (2016), studying the initial development of sorghum with organomineral fertilizers, found increases in chlorophylls $a$ and $b$ in relation to the absence of fertilization or mineral fertilizers.

Junek et al. (2014) states that the presence of organic compost in the fertilization increases the nutrient retention in the soil as the organic fraction increases the cation exchange capacity, resulting in less nutrient loss due to leaching and greater utilization by the plants; although compared to synthetic ones, organomineral fertilizers presents slower release.

Sousa et al. (2012b) also states that the superiority of organic sources may be related to the continuous supply of nutrients to the crop, which, despite being slower than chemical sources, allows lower losses due to leaching and percolation in the soil profile.

In this sense, in the present work, the time period in which the evaluations were carried out may not have been enough to make more of the nutrients supplied via the organic matter of the fertilizer available.

\section{Materials and methods}

\section{Plant material}

The study was conducted between January 21 and March 27, 2015, in a greenhouse at the Umuarama campus of the Federal University of Uberlândia, in the city of Uberlândia, MG, located at $18^{\circ} 91^{\prime} 86$ "south latitude and $4827^{\prime} 72$ "west longitude of Greenwich, at an average altitude of $800 \mathrm{~m}$.

\section{Experimental design}

The effects of five levels of fertilization with organomineral fertilizers formulated from two sources of organic matter were evaluated.

The experiment was conducted in a randomized complete block design with 4 replicates in a $2 \times 5+2$ factorial scheme, corresponding to 2 organomineral fertilizers elaborated with organic residues (biosolid or filter cake), 5 doses of organomineral fertilizer $\left(60,80,100,120\right.$ and $140 \%$ of $\left.\mathrm{P}_{2} \mathrm{O}_{5}\right)$ based on the recommended $\mathrm{P}_{2} \mathrm{O}_{5}$ dose for maize according to the Recommendation for use of correctives and fertilizers in Minas Gerais (Alves et al., 1999) and that corresponded to $120 \mathrm{~kg} \mathrm{ha}^{-1}$ of $\mathrm{P}_{2} \mathrm{O}_{5}$; a positive control corresponding to mineral fertilization ( $100 \%$ of the recommended dose) and another negative control that did not receive fertilization, totaling 12 treatments (Supplementary table 1.) and 48 plots.

Fertilizers were elaborated in formulation 5-17-10 (0.1\% Boron $+3 \%$ Silicon $+8 \%$ COT) and produced by the company Geociclo, located in Uberlândia-MG. In the treatment exclusively with mineral fertilization, the formulation 5-1710 was prepared using urea (42\%), simple superphosphate $(18 \%)$ and potassium chloride $(58 \%)$ to supply nitrogen, phosphorus and potassium, respectively. These sources were homogenized and applied to the soil to supply $100 \%$ of the $\mathrm{P}_{2} \mathrm{O}_{5}$ recommendation for the maize crop. In this way, the application of $1.76 \mathrm{~g}$ of the formulation $5-17-10$ in $5 \mathrm{~kg}$ of soil (corresponding to $120 \mathrm{~kg} \mathrm{ha}^{-1}$ of $\mathrm{P}_{2} \mathrm{O}_{5}$ ) was carried out.

\section{Conduction of experiment}

The plots of the treatments were composed of two pots with capacity of five kilograms of soil seeded with four seeds of the hybrid DKB 390 at a depth of three centimeters.

After 15 days the thinning was done leaving two plants per pot. Coverage was applied with $70 \mathrm{~kg} \mathrm{ha}^{-1}$ of ammonium sulfate $(20 \% \mathrm{~N})$ when the plants had eight fully developed leaves.

The soil used was collected at the Capim Branco experimental farm of the Federal University of Uberlândia Uberlândia, MG and characterized as an Eutrophic Red Latosol according to the methodology of Embrapa (2013) (Supplementary table 2).

It was not necessary to apply acid correctives, since it was within the ideal $\mathrm{pH}$ range accepted in the culture literature. 
The organomineral fertilizer was formulated by the company Geociclo through the enrichment of organic fertilizers with mineral fertilizers. In the first place, a stable compound was obtained by means of composting the organic sources; after that, nutrients were balanced according to the requirements of the crop and what the soil can offer.

REGULATION NR. 25, OF JULY 23, 2009, SECTION V, Art. 8, § 1 (Ministry of Agriculture, Livestock and Food Supply, 2009) states that organomineral fertilizers must comply with specifications and guarantees established by MAPA. The following parameters are established: minimum $8 \%$ organic carbon, maximum $30 \%$ humidity, minimum cation exchange rate of 80 mmole $\mathrm{kg}^{-}{ }^{1}$ and at least $10 \%$ declared macronutrients for products with primary macronutrients.

Sewage sludge was obtained as a by-product of the urban sewage treatment processes at Municipal Water and Sewage Department - DMAE, located in the city of Uberlândia, MG. The filter cake was obtained from the process of treatment and clarification of the sugarcane juice done at the sugar and alcohol industry company Vale do Tijuco, located in the city of Uberaba, MG. The sewage sludge was sanitized with hydrated lime in the proportion of $30 \%$ in the dry base aiming at the elimination of the pathogens and the reduction of humidity was carried out through natural drying in the sun for 7 days, according to methodology developed by Alves Filho (2014). After this treatment the sewage sludge is renamed here as biosolid.

Organomineral fertilizers and exclusively mineral sources were homogenized to the soil through plastic bags.

The chemical characteristics of the biosolids and the filter cake were analyzed in the Laboratory of Soil Analysis of the Federal University of Uberlândia (Supplementary table 3 and 4).

\section{Assessment of traits}

At 35 and 65 days after sowing (DAS) the plant height, stem diameter, green and dry mass of shoots and roots were evaluated, and the mass evaluations were performed at 65 DAS. In addition, chlorophyll A and chlorophyll B were also measured at 35 DAS.

Plant height measurement was performed at ground level up to the curvature of the last fully expanded leaf with a graded grid in $\mathrm{cm}$; the stalk diameter was measured $1 \mathrm{~cm}$ above ground level by a digital caliper calibrated in millimeters.

At 65 DAS the plants were harvested and separated in aerial part and root. The wet mass of these parts was then measured and the material was dried in a forced air circulation oven at 65 ㅇ $\mathrm{C}$ for 72 hours and again the mass was checked.

Chlorophylls A and B were evaluated by the Clorofilog ${ }^{\circledR}$ chlorophyll meter, and the last two leaves were selected per plant, totaling eight samples for each plot.

\section{Statistical analyses}

The data were initially tested for residual normality assumptions (Shapiro-Wilk test), homogeneity of variances (Levene test) and block additivity (Tukey's test for additivity), using SPSS software version 20.0. All data were submitted to 0.01 significance.
Subsequently, the evaluated characteristics were submitted to the $F$ test of the analysis of variance and the study of the sources of organomineral fertilizers was done by the Tukey test to compare the means of the treatments. The study of the doses of organomineral fertilizers was performed by regression to obtain a statistical model. For the additional treatments, the positive and the negative control, the Dunnett's test was applied, in which the analyzes were performed at the 0.05 level of significance, using Assistat statistical software version 7.6 beta (Silva, 2016).

Sigma Plot software for Windows Version 11.0 Build 11.0.0.77 was used to search for regression models of quantitative data, admitting as good models those that were significant and with coefficient of determination $\left(R^{2}\right)$ above $70 \%$.

All variables met the assumptions at 0.01 of significance, except for the root dry mass which, even after transformation of $\mathrm{V} x$, did not take into account the normality of residues and the homogeneity of the variances.

\section{Conclusion}

Organomineral fertilizers with biosolids and filter cake provided plant height and stem diameter at 35 DAS higher than those provided by mineral fertilizer. The stem diameter at 35 DAS showed linear growth as the doses of organomineral fertilizers were increased. Regardless of the applied dose, the organomineral fertilizer with biosolids provided greater production of green mass of the aerial part in relation to the filter cake. The green and dry masses of the root were higher in the higher doses of organomineral fertilizers, in relation to mineral fertilization. Biosolids, as well as filter cake fertilizer, represent an important way of recycling organic matter and nutrients with good use of these residues in agriculture, and are proving to be a viable and efficient alternative to organomineral fertilizer for total or partial replacement of mineral fertilization.

\section{Acknowledgments}

The authors are grateful to the Institute of Agricultural Sciences - ICIAG / UFU, FAPEMIG, Geociclo and Vale do Tijuco for support and financial support for the research.

\section{References}

Anetor MO, Omueti JAI (2014) Organo-mineral fertilizer effects in some phosphorus-unresponsive soils of southwestern Nigeria: 1. Effects on maize growth response and soil properties. Agric. Biol. J. North Am. 5(6):265-280.

Alves Filho A (2014) Desinfecção de lodo de esgoto anaeróbico para fins agrícolas. 79. Uberlândia: Federal University of Uberlândia, 2012. Dissertation. $79 \mathrm{f}$.

Alves VMC, Casconcellos CA, Freire CA; Pitta GV, França GE, Filho AR, Araújo JM, Vieira JR, Loureiro JE (1999) Milho. In: Ribeiro AC, Guimarães PTG, Alvarez VVH (eds) Recomendação para o uso de corretivos e fertilizantes em Minas Gerais - 5. Aproximação. Comissão de fertilidade do solo do Estado de Minas Gerais. Viçosa. p 381-383.

Benites VN, Correa JC, Menezes JFS, Polidoro JC (2010) Produção de fertilizante 
organomineral granulado a partir de dejetos de suínos e aves no Brasil. In: Fertbio, Guarapari. $p 4$.

Bettiol W, Camargo OA, Galvão JAH, Ghini R (2006) Impacto ambiental do uso agrícola do lodo de esgoto: Descrição do estudo. In: Bettiol W, Camargo OA (eds) Lodo de Esgoto: Impactos Ambientais na Agricultura. Embrapa Meio Ambiente. Jaguariúna. p. 17-23.

Borsari F (2013) Fertilizantes inteligentes. Rev AgroDBO. 45: 54-57.

Carvalho RP, Moreira RA, Cruz MCM, Fernandes DR, Oliveira, AF (2014) Organomineral fertilization on the chemical characteristics of Quartzarenic Neosol cultivated with olive tree. Scientia Hortic.176: 120-126, 2014.

Deeks L, Chaney K, Murray C, Sakrabani R, Gedara S, Le M, Tyrrel S, Pawlett M, Read R, Smith G (2013) A new sludgederived organo-mineral fertilizer gives similar crop yields as conventional fertilizers. Agron Sustain Dev. 33(3):539549.

Embrapa-Empresa brasileira de pesquisa agropecuária (2013) Sistema brasileiro de classificação de solos, 3rd edn. Brasília. p 353.

Frazão JJ (2013) Eficiência agronômica de fertilizantes organominerais granulados à base de cama de frango e fontes de fósforo. Goiás: Federal University of Goiás, 2013. Dissertation. $90 \mathrm{f}$.

Junek JOMO, Lara TS, Paiva MJA, Martins DB, Morais CG (2014) Fertilizantes organominerais. Circular técnica 06. Inst Cienc Saúde, Agr e Hum (ISAH).

Korndörfer GH (2003) Resposta da cultura da cana-deaçúcar à adubação fosfatada. Informações Agronômicas, Piracicaba. 102: 7.

Kominko H, Gorazda K; Wzorek Z (2017) The possibility of organo-mineral fertilizer production from sewage sludge. Waste and Biomass Valorization. 8( 5):1781-1791, 2017.

Lana RP, Guimarães G, Alcântara PHR, Baracho FAO, Silva PT, Andrade FL,Vargas LM (2009) Correlações entre algumas variáveis produtivas e parâmetros cinéticos da produção de milho em função de níveis de adubação. Paper presented at the Simpósio brasileiro de agropecuária sustentável, Viçosa, p 568-573 2009.

Martins DC, Resende AV, Galvao JC, Simão EP, Almeida GO, Ferreira HH (2016) Características agronômicas de milho adubado com fertilizantes organominerais a base de cama de frango e fosfatos. Paper presented at teh XXXI Congresso nacional de milho e sorgo, Bento Gonçalves, $p$ 404-407, 2016.
Melo WJ, Marques MO (2000) Potencial do lodo de esgoto como fonte de nutrientes para as plantas. In: Bettiol W, Camargo OA (ed) Impacto ambiental do uso agrícola do lodo de esgoto. Emb M Amb. Jaguariúna, p 109-141.

Mendes P, Rodrigues E, Rodrigues Filho F (2011) Uso de biossólido na cultura do milho (Zea mays L.): avaliação das propriedades físicas e químicas e sua influência no crescimento da planta. Cadernos de Agroecologia. 6 (2):5.

Nunes Júnior D (2008) Torta de filtro: de resíduo a produto nobre. Idea News, Ribeirão Preto. 8(92): 22-30.

Oliveira DP (2016) Fontes de matéria orgânica para a formulação de fertilizantes organominerais peletizados no desenvolvimento da cultura do sorgo. Uberlândia: Federal University of Uberlândia, 2016. Dissertation. $46 \mathrm{f}$.

Santana CTC (2012) Comportamento de milho (Zea mays L.) e propriedades físicas do solo, no sistema plantio direto, em resposta a aplicação de fertilizante organomineral. Botucatu: UNESP, 2012. Dissertation. $49 \mathrm{p}$.

Silva AA, Costa AM, Lana RMQ, Lana AMQ (2012) Reciclagem de nutrientes com aplicação de resíduos orgânicos em pastagens degradadas. Eng Agr. 32(2): 405- 414.

Silva FAS (2016) ASSISTAT: Versão 7.7 beta. DEAG-CTRNUFCG . Updated January 3, 2016. Available at: <http://www.assistat.com/indexp.htm>. Accessed on: Sep. 25, 2016.

Sousa RTX, Henrique HM, Korndörfer GH (2012a) Teste de performance em híbridos de Milho com uso de Geofert em Santana de Vargem - MG. Empresa Geociclo. p 10.

Sousa RTX, Henrique HM, Korndörfer GH (2012b) Uso de fertilizante organomineral e a produtividade de híbridos de milho. Geofert. p 10.

Streit NM, Canterle LP, Canto, MWC, Hecktheuer LH (2005). As Clorofilas. Ciênc Rural. 35(3): 748-755.

Teixeira WG (2013) Biodisponibilidade de fósforo e potássio provenientes de fertilizantes mineral e organomineral. Uberlânida: Federal University of Uberlândia, 2013. Dissertation. $115 \mathrm{f}$.

Tiritan CS, Santos DH (2012) Resposta do milho safrinha a adubação organomineral no município de Maracaju-MS Colloq Agrar. 8: 24-31.

Tiritan CS, Santos DH, Foloni JSS, Júnior RA (2010) Adubação fosfatada mineral e organomineral no desenvolvimento do milho. Colloq Agrar. 6 (1): 8-14.

Tozatti, G. O uso de fertilizante organomineral. In Simpósio IPNI EECB. Bebedouro, 2013. 